\title{
Seedling drought stress susceptibility in two deciduous Nothofagus species of NW Patagonia
}

Article in Trees · June 2010

DOI: $10.1007 / 500468-010-0412-2$

CITATIONS

17

4 authors:
READS

\section{Santiago Agustín Varela}

Instituto Nacional de Tecnología Agropecuaria 20 PUBLICATIONS 60 CITATIONS

SEE PROFILE

\section{María Elena Fernández}

National Scientific and Technical Research C... 81 PUBLICATIONS 696 CITATIONS

SEE PROFILE

\section{Javier Gyenge}

National Scientific and Technical Research C... 81 PUBLICATIONS 652 CITATIONS

SEE PROFILE

\section{Tomás Schlichter}

Instituto Nacional de Tecnología Agropecuara 63 PUBLICATIONS 853 CITATIONS

SEE PROFILE

Some of the authors of this publication are also working on these related projects:

Seed bank of a burned Nothofagus pumilio forest: Effect of biosolids compost application View 


\title{
Seedling drought stress susceptibility in two deciduous Nothofagus species of NW Patagonia
}

\author{
Santiago Agustín Varela $\cdot$ J. E. Gyenge • \\ M. E. Fernández $\cdot$ T. Schlichter
}

Received: 18 September 2009/Revised: 30 December 2009/Accepted: 7 January 2010/Published online: 28 January 2010

(C) Springer-Verlag 2010

\begin{abstract}
The physiological capacities of seedlings to cope with drought may be subject to strong selective pressure in the context of future climate scenarios, threatening the regeneration and sustainability of forests. Characterization of the responses and the variability between species is of interest to breeding and domestication programs. In this study, our main goal was to describe some of the physiological mechanisms involved in the drought response of Nothofagus nervosa and N. obliqua, two forest species of ecological and commercial importance (high wood quality) in NW Patagonia. We tested for differences in water status, gas exchange and survival in response to a gradually imposed severe drought. Based on cavitation vulnerability curves and hydraulic conductivity measurements, we can conclude that $N$. obliqua stems have higher specific hydraulic conductivity and somewhat lower vulnerability to cavitation than $N$. nervosa stems, leading it to sustain higher stomatal conductance under non-severe drought conditions. $N$. obliqua had higher photosynthetic capacity than $N$. nervosa, due both to characteristics of its hydraulic architecture and to its higher metabolic capacity. Our results indicate that both species present characteristics of plants susceptible to water stress. Also, both species
\end{abstract}

Communicated by T. Grams and R. Guy.

S. A. Varela $(\varangle)$ · J. E. Gyenge · M. E. Fernández .

T. Schlichter

Grupo de Ecología Forestal, Instituto Nacional de Tecnología

Agropecuaria, INTA Estación Experimental Agropecuaria

Bariloche, CC 277, 8400 San Carlos de Bariloche,

Rio Negro, Argentina

e-mail: svarela@bariloche.inta.gov.ar

J. E. Gyenge · M. E. Fernández

Consejo Nacional de Investigaciones Científicas y Técnicas,

CONICET, Buenos Aires, Argentina showed behavior resembling an anisohydric response. This behavior results from a lack of stomatal control over transpiration while the soil dehydrates, probably accompanied by very high vulnerability to cavitation. In contrast, both species had similar high stomatal sensitivity to vapor pressure deficit when soil water was limiting.

Keywords Stomatal conductance - Drought avoidance . Water stress · Seedlings

\section{Introduction}

Extreme climatic events such as regional droughts are likely to produce rapid, profound, long-lasting effects on ecosystems and landscapes if large numbers of individuals of dominant or key species disappear (IPCC 2008). Particularly for areas with Mediterranean-type climate, global climate models forecast an increase in water deficits and drought risks as well as fluctuations in precipitation events.

In regions with Mediterranean-type climates, the existing knowledge on the response of various tree species to drought is patchy. For example, the physiological responses of European species of the genus Quercus and Fagus are well known (Cochard et al. 2000; Corcuera et al. 2002; Lemoine et al. 2002; Aranda et al. 2004; Lendzion and Leuschner 2008), while the knowledge of the drought response of species in many other regions with Mediterranean-type climate, including northern Patagonia on the western rim of South America, is limited to just a few species (Suarez et al. 2004; Gyenge et al. 2007; Martinez Pastur et al. 2007; Piper et al. 2007; Peri et al. 2009), or even non-existent for other important forest species.

Differences in the degree and type of environmental stress, biomass allocation patterns, ontogenic changes in 
stress susceptibility, growth variability and genetic variability in drought resistance may differentially predispose seedlings and adult trees to remain alive or to die during severe droughts. In this sense, the development of adaptive strategies during early ontogeny seems to be the determining factor for survival in habitats with drought stress (Pratolongo et al. 2003). Moreover, these traits may be critical for predicting community-level responses to altered climatic regimes, yet they are poorly known for many species (Suarez et al. 2004). Co-occurring Mediterranean tree species often show different water-use strategies in response to drought (mainly avoidance or tolerance; Martinez-Ferri et al. 2000). These water use strategies are partly related to strategies concerning water status regulation (water potential; Tardieu and Simoneau 1998), which in turn affect carbon fixation during drought. In this regard, different species may develop two opposite types of behavior: (a) isohydric control of water potential (avoidance mechanism by stomata closure; Tyree and Sperry 1988) or (b) anisohydric behavior (generally seen as a drought tolerance mechanism in which stomatal closure is less strict; McDowell et al. 2008), or any of multiple intermediate situations. Regarding anisohydric behavior, it is important to distinguish this type, which occurs in drought tolerant species, from the anisohydric behavior of some non-drought adapted species. Some species may exhibit anisohydric behavior as a result of a lack of stomatal control of transpiration and water potential, and simply desiccate and die when exposed to drought (runaway cavitation theory; Tyree and Sperry 1988).

In NW Patagonia, South America, the presence of the Andean range generates a steep West-East precipitation gradient and additionally, due to differences in mean annual precipitation values, inter-annual variation is high (Jobbágy et al. 1995). Climate models predict an increase in precipitation variability for the Patagonian region with a trend towards decreased water inputs (IPCC 2008). Therefore, more frequent and/or intense drought periods may have negative impacts on the survival, regeneration and productivity of some vegetation systems in this region (Suarez et al. 2004).

In Argentina, Patagonian-Andean forests occupy a narrow strip, no more than $100-\mathrm{km}$ wide, covering many degrees of latitude $\left(36^{\circ} \mathrm{S}-55^{\circ} \mathrm{S}\right)$. Species belonging to the genus Nothofagus (Nothofagaceae) represent $80 \%$ of the Patagonian-Andean forests (Veblen et al. 1996). This genus includes six species in Argentina, which have high ecological and commercial importance. Two of these six species are the deciduous $N$. nervosa (Phil.) Krassen and $N$. obliqua (Mirb.) Oerst., both included in breeding and domestication programs and in actions leading to conservation of forest diversity of Patagonian temperate forests (Gallo et al. 2009).
In Argentina, $N$. nervosa grows from $39^{\circ} 25^{\prime} \mathrm{S}$ to $40^{\circ} 35^{\prime} \mathrm{S}$ in a small geographical range at elevations of $800-1,000 \mathrm{~m}$ asl, where general environmental conditions remain relatively homogeneous, with dry summers and a wide temperature range. Mean annual precipitation at these sites ranges from 1,200 to 3,000 mm/year (Marchelli 2001). West-east prevailing winds are particularly important in modeling their expected pattern of genetic variation, conditioning a unidirectional genetic flow (Gallo et al. 2004).

Nothofagus obliqua is distributed from $36^{\circ} 50^{\prime} \mathrm{S}$ to $40^{\circ} 15^{\prime} \mathrm{S}$, showing a markedly fragmented pattern of distribution and a stronger association with a pluviometric gradient ( $680 \mathrm{~mm}$ to $3,000 \mathrm{~mm} / \mathrm{year}$; Barbero 2008). In its range of distribution, $N$. obliqua grows at elevations of 650-1,000 $\mathrm{m}$ asl (Donoso et al. 2007). It is distributed over four lake basins, in two of which (Quillen and Lacar) it occurs in sympatry with $N$. nervosa. There is a fairly isolated population (Pilolil) at approximately the same latitude as Lake Quillen, but $30 \mathrm{~km}$ farther east, where environmental conditions (mainly lower rainfall) are different from those of the "central" distribution of this species in Argentina. The presence of this N. obliqua population in more xeric conditions suggests that the species, or at least that population within the species, can have differential drought resistance strategies compared to $N$. nervosa.

During recent years, efforts have been made to characterize the genetic variability and identify natural interspecific hybrids (e.g. Gallo et al. 2004; Premoli 2004) of Nothofagus species in Patagonia. However, the physiological implications of genetic differences have not been studied. This information could be valuable for genetic improvement and breeding programs, as well as for predicting the response of different provenances to climatic change (Kozlowski and Pallardy 2002; Valladares 2004).

Based on this background, our main goal was to describe the drought responses at the species level in $N$. nervosa and $N$. obliqua seedlings, analyzing ecophysiological variables such as stomatal conductance, net photosynthetic rates and predawn and midday water potentials, as well as the plant survival under drought conditions. Based on the small differences in geographical distribution of the two species, we expected a generally similar response but with some variables indicating a slightly better performance of $N$. obliqua under drought conditions.

\section{Materials and methods}

Study site and plant material

The experiment was performed on 2-year-old $N$. nervosa and $N$. obliqua seedlings in a greenhouse at the National Institute for Agricultural Technology (INTA) Experimental 
Station, Bariloche, Argentina, in November and December 2008. Late spring was selected rather than summer mainly to avoid excessively high mean and maximum greenhouse temperatures.

In order to cover the potential genetic variation associated with geographic distribution of the two species, all measurements were carried out on potted seedlings grown from seeds collected from four provenances of the natural distribution range of each species (Table 1). After harvesting, the seeds were mixed with moist sand and placed in plastic bags at a temperature of $4-5^{\circ} \mathrm{C}$ for a period of 45 days for stratification.

One month before the beginning of the experiment, all the seedlings were transplanted from their original containers to $3-1$ plastic pots $(20 \mathrm{~cm}$ height $)$ and watered daily. To select the pot volume for the experiment, we previously determined mean daily transpiration rates of the seedlings. We then chose a pot size that would ensure water availability above the permanent wilting point (PWP) for at least 1 week without watering. This enabled us both to maintain adequate soil moisture levels for control plants (close to field capacity, FC) and to generate fairly gradual soil desiccation under the drought treatment. For all seedlings we used a sandy loam soil (clay $=6.6 \%$, silt $=41.9 \%$, sand $=51.5 \%$ ) similar to soils in which natural forests develop. The water retention curve of the soil $(-0.03 ;-0.1 ;-0.15 ;-0.7$ and $-1.5 \mathrm{MPa})$ was developed in the Soil Laboratory of INTA EEA Bariloche.

\section{Experimental design}

In early November 2008 we selected the 80 most evenly sized plants of each species (20 of each provenance), of similar height, basal diameter and number of leaves, also ensuring similar plant sizes between species. Watering was suspended for 40 randomly chosen individuals of each species, while the remaining 40 were kept well watered, close to FC. A 3-week drought cycle was imposed.
Measurements of soil volumetric water content (VWC) and micrometeorological variables

We transformed gravimetric water content values of field capacity (FC) and permanent wilting point (PWP) of the water retention curves $(-0.03$ and $-1.5 \mathrm{MPa})$ to volumetric values in order to ensure that the watering conditions of the control plants were suitable and to quantify the degree of water shortage in the drought stress treatment. Soil moisture was recorded three times a week throughout the study period as the volumetric water content (VWC, \% $\mathrm{vol} / \mathrm{vol}$ ) using a time domain reflectometry (TDR) soil moisture meter (TRIME-FM; IMKO, Ettlingen, Germany) with an $18 \mathrm{~cm}$ trident probe (P3 model; IMKO, Ettlingen, Germany). Values of FC and PWP were compared to record VWC at each date for each treatment. Soil moisture measurements were carried out in 20 pots with plants of each species and treatment.

Mean daily temperature $\left({ }^{\circ} \mathrm{C}\right)$ and mean daily relative air humidity (\%) were registered in the greenhouse using a thermohygrometer (HOBO, Onset Computer Corporation, USA). Vapor pressure deficit (VPD, $\mathrm{kPa}$ ) was estimated according to Ewers and Oren (2000).

Plant water status: predawn $\left(\Psi_{\mathrm{pd}}\right)$ and midday $\left(\Psi_{\mathrm{md}}\right)$ water potential

In order to characterize the plant water status in response to drought stress, predawn and midday leaf water potential were measured on two different dates at the end of the drought cycle. Measurements were carried out with a pressure chamber (PMS 1000, PMS Instruments, Corvallis, Oregon, USA) using one leaf per plant in 20-40 seedlings per species. In all cases we selected fully expanded leaves from the top third of the seedling. The proportion of cut leaves was low in relation to total leaf area, ensuring that the other physiological variables measured were not affected. For the measurements, we selected plants in

Table 1 Climatic characteristics of provenance areas where seeds were collected

\begin{tabular}{|c|c|c|c|c|c|}
\hline Species & Provenance & Latitude (S) & Longitude (W) & Altitude (m) & Precipitation $\left(\mathrm{mm}\right.$ year $\left.^{-1}\right)$ \\
\hline \multirow[t]{4}{*}{ N. nervosa } & Tromen & $39^{\circ} 34^{\prime} 32^{\prime \prime}$ & $71^{\circ} 25^{\prime} 48^{\prime \prime}$ & 1,040 & 3,000 \\
\hline & Curruhue & $39^{\circ} 51^{\prime} 00^{\prime \prime}$ & $71^{\circ} 29^{\prime} 24^{\prime \prime}$ & 970 & 970 \\
\hline & Paimún & $39^{\circ} 42^{\prime} 00^{\prime \prime}$ & $71^{\circ} 34^{\prime} 12^{\prime \prime}$ & 970 & 970 \\
\hline & Queñi & $40^{\circ} 10^{\prime} 12^{\prime \prime}$ & $71^{\circ} 46^{\prime} 12^{\prime \prime}$ & 900 & 900 \\
\hline \multirow[t]{4}{*}{ N. obliqua } & Yuco & $40^{\circ} 09^{\prime} 07^{\prime \prime}$ & $71^{\circ} 30^{\prime} 39^{\prime \prime}$ & 930 & $1,600-1,800$ \\
\hline & Pío Proto & $40^{\circ} 06^{\prime} 48^{\prime \prime}$ & $71^{\circ} 14^{\prime} 31^{\prime \prime}$ & 980 & $1,200-1,400$ \\
\hline & Quillén & $39^{\circ} 22^{\prime} 16^{\prime \prime}$ & $71^{\circ} 17^{\prime} 31^{\prime \prime}$ & 1,140 & $1,800-2,000$ \\
\hline & Pilolil & $39^{\circ} 30^{\prime} 05^{\prime \prime}$ & $70^{\circ} 57^{\prime} 44^{\prime \prime}$ & 836 & 680 \\
\hline
\end{tabular}

Data of latitude and longitude were registered with GPS, elevation was registered with altimeter and mean annual precipitation was estimated from isohyet maps (Martinez, pers. comm.) 
which VWC the day previous to water potential measurement was close to FC (control plants) and with very low VWC values $(0-5 \% \mathrm{vol} / \mathrm{vol})$, in order to determine the minimum water potential values that each species can reach.

\section{Leaf gas exchange}

In order to characterize the effect of drought stress on net carbon fixation, net photosynthetic rate was measured in fully expanded leaves of 20 randomly selected plants per species and treatment (five of each provenance), using an LI-6400 portable photosynthesis measuring system (LI-COR, Lincoln, Nebraska, USA) with a 6400-02B LED source providing a photosynthetic photon flux density (PPFD) of $1,000 \mu \mathrm{mol} \mathrm{m}{ }^{-2} \mathrm{~s}^{-1}$ (this level of radiation was above saturation point for these species). The atmosphere of the chamber was maintained at $20^{\circ} \mathrm{C}, 60 \%$ relative humidity, with a $\mathrm{CO}_{2}$ concentration of $400 \mathrm{ppm}$. In all cases, leaves were large enough to completely fill the cuvette of the gas exchange system. Net photosynthetic rate $\left(A_{\text {net }}, \mu \mathrm{mol} \mathrm{CO}_{2} \mathrm{~m}^{-2} \mathrm{~s}^{-1}\right)$, stomatal conductance $(\mathrm{gs}$, mol $\left.\mathrm{H}_{2} \mathrm{O} \mathrm{m}^{-2} \mathrm{~s}^{-1}\right)$, and leaf transpiration rate $(E, \mathrm{mmol}$ $\mathrm{H}_{2} \mathrm{O} \mathrm{m}^{-2} \mathrm{~s}^{-1}$ ) were registered at the end of the drought cycle. The instantaneous water use efficiency (WUE) was calculated as $A_{\text {net }} / E$ ( $\mu$ mol $\mathrm{CO}_{2}$ fixed per mmol of transpired $\mathrm{H}_{2} \mathrm{O}$ ). Stomatal conductance ( $\mathrm{gs}$, mol $\mathrm{H}_{2} \mathrm{O} \mathrm{m} \mathrm{m}^{-2} \mathrm{~s}^{-1}$ ) was also measured 3 days a week in fully expanded leaves of 20 plants per species and treatment with an EGM-4 porometer (PP Systems, Amesbury, Massachusetts, USA) from 9:00 to 11:00 am (midmorning) and 2:00 to 6:00 pm (afternoon). In addition, we estimated the stomatal sensitivity of both species as in Oren et al. (1999) using the values of gs and VPD measured concurrently with $A_{\text {net }}$. Stomatal conductance measurements performed with the LI-COR 6400 were never compared with values registered with the EGM-4 porometer.

\section{Apex mortality}

In order to characterize the effect of drought stress on plant survival and some morphological traits related to wood quality, at the end of the drought cycle, we recorded the survival of the plant apex (top third) in each treatment as the number of apparently dead plants (those with dead apex, including plants which could probably resprout) over the total number of plants considered in the assay multiplied by 100 [survival percentage (\%)].

\section{Additional measurements}

In order to evaluate the differences in some physiological traits between species, not including drought responses, a set of seedlings of different provenances growing under adequate water supply was assessed. Pressure-volume $(P-V)$ curves were used to assess osmotic potential and cell wall elasticity, and assimilation versus internal $\mathrm{CO}_{2}$ concentration $(A-\mathrm{Ci})$ curves to distinguish between stomatal limitation and metabolic limitation of photosynthetic rates. $P-V$ curves were developed by means of the "free transpiration technique" following Corcuera (2003). Six to 12 twigs with fully developed leaves were excised from each species. The following parameters were estimated from the $P-V$ curve: the osmotic potential at saturation $\left(\Psi_{\pi \mathrm{sat}}, \mathrm{MPa}\right)$, water potential at turgor loss full point $\left(\Psi_{\mathrm{tlp}}, \mathrm{MPa}\right)$, the relative water content at turgor loss point $\left(\mathrm{RWC}_{\mathrm{tlp}}\right)$, the maximum modulus of elasticity $\left(\varepsilon_{\max }, \mathrm{MPa}\right)$ of cell walls, and the apoplastic relative water content $\left(\mathrm{RWC}_{\mathrm{apop}}\right)$.

As mentioned, $A-\mathrm{Ci}$ curves enabled us to distinguish between stomatal and metabolic limitations of photosynthesis of the seedlings of the two species under adequate water supply. We used an LI-6400 infrared gas analyzer (LICOR, Lincoln, Nebraska, USA) with a 6400-02B LED source, using $\mathrm{CO}_{2}$ concentrations of 50, 100, 200, 300, 400, 600,800 and $1,000 \mathrm{ppm}$, a chamber temperature of $20^{\circ} \mathrm{C}$ and a PPFD of $1,500 \mu \mathrm{mol}$ photon $\mathrm{m}^{-2} \mathrm{~s}^{-1}$. Parameters of $A-\mathrm{Ci}$ curves were obtained using the $A / \mathrm{Ci}$ curve fitting utility version 1.1. Software (Sharkey et al. 2007). This software enables the following parameters to be estimated:

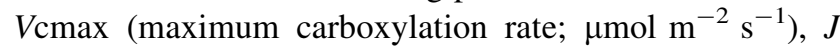
(maximum photosynthetic electron transport based on NADPH requirement; $\mu \mathrm{mol} \mathrm{m} \mathrm{m}^{-2} \mathrm{~s}^{-1}$ ), Rd (rate of day respiration; $\mu \mathrm{mol} \mathrm{m} \mathrm{m}^{-2} \mathrm{~s}^{-1}$ ) and gm (mesophyll conductance; $\mathrm{mol} \mathrm{m}^{-2} \mathrm{~s}^{-1}$ ). The latter was estimated as in Ethier and Livingston (2004).

On the same set of seedlings and in order to characterize the maximum stem hydraulic conductivity of each species and the vulnerability to xylem cavitation, vulnerability to drought-induced xylem cavitation was measured as the reduction in hydraulic conductivity of a stem as a function of xylem pressure induced by air injection with a modified pressure chamber. For the measurement we followed the procedure described by Maherali and de Lucia (2000). Considering that the maximum length of vessels of both species was about $30 \mathrm{~cm}$, segments $40 \mathrm{~cm}$ long (or the whole stem when seedlings were shorter) were excised, debarked and all lateral branches cut to provide an entry point for air. All these procedures were carried out under water. To determine the maximum hydraulic conductivity $\left(k_{\max }\right)$ of each stem, before the induction of cavitation, the segment was cleared of existing air embolism using filtered water at $120 \mathrm{kPa}$ for $15 \mathrm{~min}$. Percent loss in conductivity (PLC) following each chamber pressurization was calculated as $\mathrm{PLC}=100\left(\left(k_{\max }-k_{\mathrm{h}}\right) / k_{\max }\right)$ were $k_{\mathrm{h}}$ is hydraulic 
conductivity of the segment measured after each chamber pressurization. Vulnerability curves were fitted to the model proposed by Pammenter and Vander Willigen (1998) and parameters $a$ (the degree to which conductivity responds to injection of pressure, curve shape) and $b$ (xylem water potential at which a $50 \%$ loss in conductivity occurs) were estimated.

\section{Statistical analysis}

Statistically significant differences in soil water content (VWC); predawn and midday water potential $\left(\Psi_{\mathrm{pd}}, \Psi_{\mathrm{md}}\right)$, net photosynthetic rate $\left(A_{\text {net }}\right)$, stomatal conductance $(\mathrm{gs})$, transpiration $(E)$ and instantaneous water use efficiency (WUE) between species and treatments were tested using one-way ANOVA. When data did not fulfill statistical assumptions, we used non-parametric Mann-Whitney (Wilcox) two-sample tests and Kruskal-Wallis test. Comparisons between $P-V, A-C i$ curves and vulnerability to drought-induced xylem cavitation curves of both species were analyzed using $F$ tests. The parameters of three curves were compared between species using one-way ANOVA, non-parametric Mann-Whitney two sample test and $t$ tests.

Plant apex survival was compared between species and treatments using generalized linear/nonlinear models (GLZ). Additionally, as a preliminary assessment, we tested for intra-specific differences for most of the measured variables comparing results of the different provenances within species (Table 1). For the latter, statistically significant differences were tested using one-way ANOVA; in all cases, $\alpha=5 \%$ was used.

\section{Results}

Soil water content and climatic variables

Mean values $( \pm S D)$ of VWC during the whole study period were $34.0 \pm 4.5$ and $32.0 \pm 7.2 \%$ for seedlings under the control treatment and $13.1 \pm 9.8$ and $9.9 .1 \pm 9.2 \%$ for stressed seedlings of $N$. nervosa and $N$. obliqua, respectively (Fig. 1). Mean VWC values in seedlings of the control treatment were always above the permanent wilting point $(\mathrm{PWP}=22.0 \% \mathrm{vol} / \mathrm{vol})$ and close to field capacity $(\mathrm{FC}=36.8 \% \mathrm{vol} / \mathrm{vol})$, while drought treatments showed similar and lower PWP values. Statistically significant differences $(p<0.05)$ in VWC between treatments were observed within 1 week after the beginning of the measurements and persisted until the end of the experiment. On each date, VWC values for each treatment were similar between species $(p>0.05)$. Mean daily temperature during the experiment ranged from 12 to $27^{\circ} \mathrm{C}$ and mean daily relative humidity ranged from 22 to $54 \%$. During the study period, VPD ranged from 1.8 to $5.3 \mathrm{kPa}$ for the midmorning measurements and from 1.6 to $6.0 \mathrm{kPa}$ during the afternoon measurements (data not shown).

Plant water status

Both species show similar values of predawn water potential independently of the VWC considered (FC or D; Fig. 2a). However, N. obliqua shows a tendency to lower values of predawn water potential under severe drought condition ( $D$; without significant statistical differences). At midday, we observed the same tendency for severe drought
Fig. 1 Pot volumetric water content (VWC $\pm \mathrm{SD}$ ) per species and treatment. Asterisks over the points on the graphs indicate statistical differences between treatments within each species. No difference was found between species within each treatment. $N n N$. nervosa, No N. obliqua, $-C$ control, $-S$ stressed, $F C$ field capacity, $P W P$ permanent wilting point

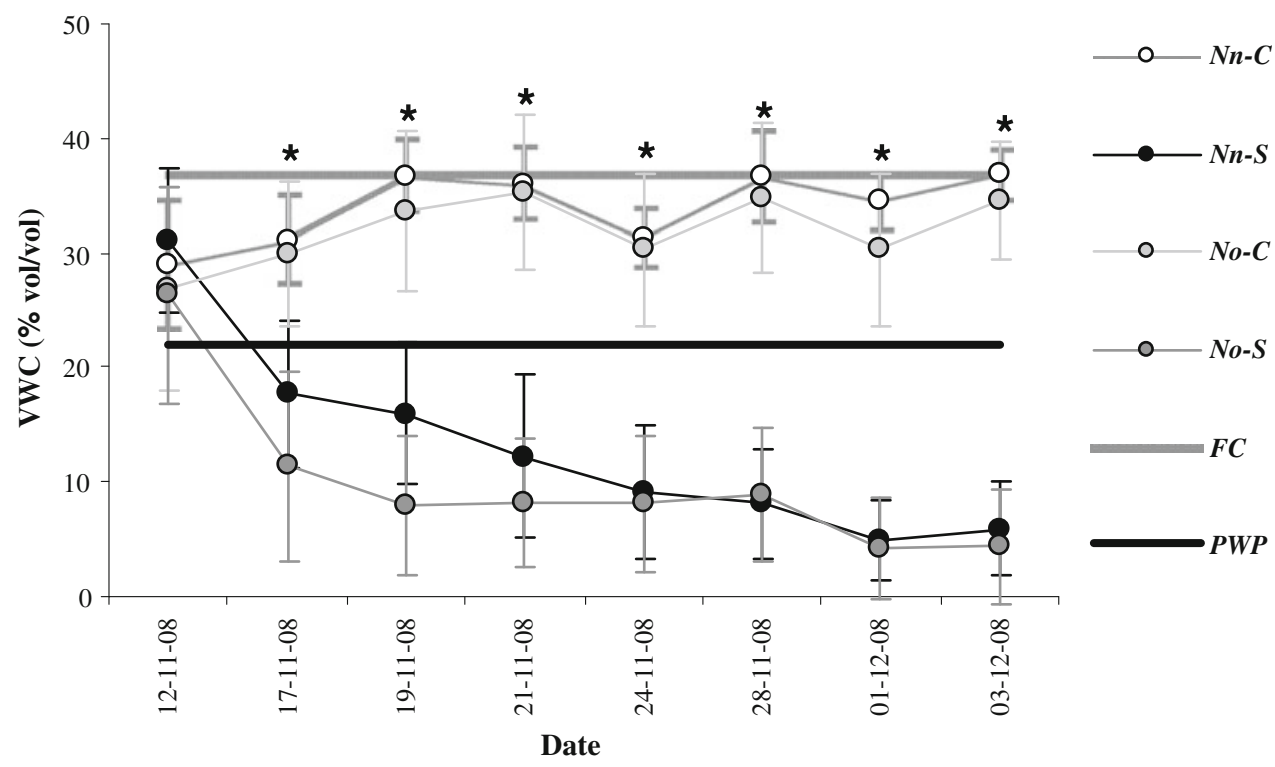



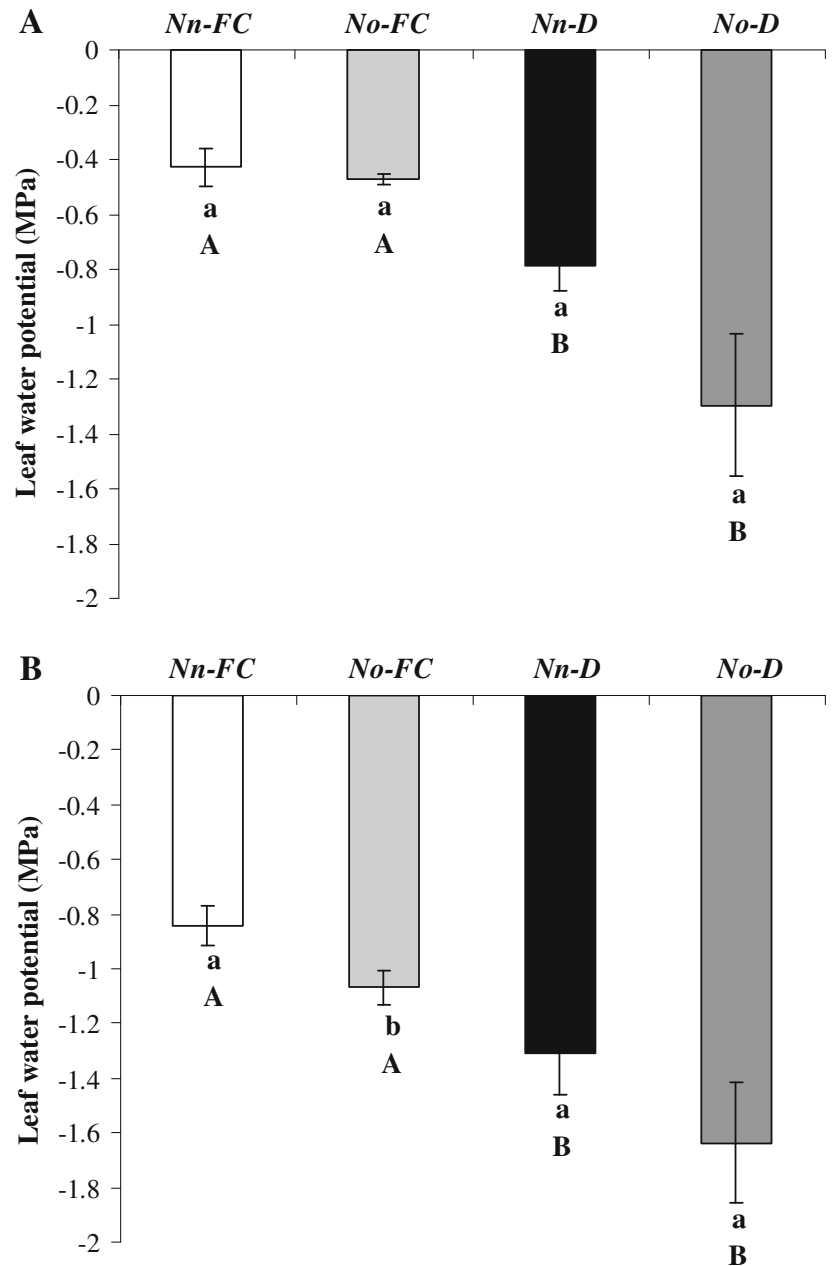

C $\Psi p d(\mathrm{MPa})$

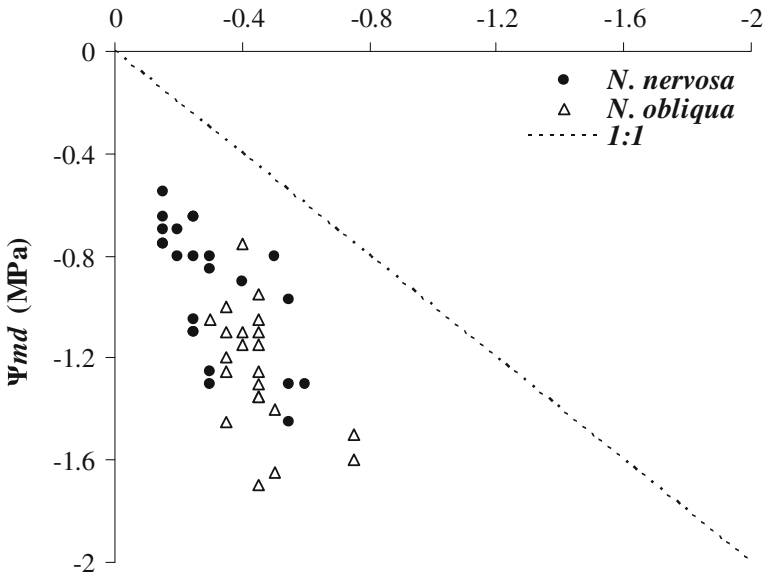

Fig. 2 Predawn (a) and midday (b) water potential $( \pm \mathrm{SD})$ in relation to pot volumetric water content (VWC, FC field capacity, $>30 \%$ $\mathrm{vol} / \mathrm{vol}$; $D$ drought, $0-5 \% \mathrm{vol} / \mathrm{vol}$ ) per species. Nn N. nervosa, No N. obliqua. Different lowercase letters show statistical differences in water potential values between species at the same VWC (FC and D). Capital letters show statistical differences between water potentials per VWC within species. $\mathbf{c}$ Relation between values of predawn water potential $\left(\Psi_{\mathrm{pd}}\right)$ and values of midday water potential $\left(\Psi_{\mathrm{md}}\right)$ per species. Black circles represent $N$. nervosa, white triangles represent $N$. obliqua, dotted line represents a 1:1 tendency conditions and also statistical differences between species under suitable water availability (FC). Under this last condition $N$. obliqua had lower values of water potential than $N$. nervosa (Fig. 2b).

Both species showed a decrease in their minimum leaf water potential (measured at midday) when predawn water potential decreased (Fig. 2c).

\section{Leaf gas exchange}

Seedlings of both species showed a high, significant reduction in net photosynthetic rate after the drought treatment $(p<0.05)$. Under control conditions, N. obliqua showed higher net photosynthetic rate than $N$. nervosa (11.7 vs. $9.2 \mu \mathrm{mol} \mathrm{CO} \mathrm{CO}_{2} \mathrm{~m}^{-2} \mathrm{~s}^{-1} ; p=0.03980$; Table 2), but both species had similar values under drought stress $\left(1.6 \mu \mathrm{mol} \mathrm{CO}_{2} \mathrm{~m}^{-2} \mathrm{~s}^{-1}\right.$ for $N$. obliqua and $1.3 \mu \mathrm{mol}$ $\mathrm{CO}_{2} \mathrm{~m}^{-2} \mathrm{~s}^{-1}$ for $N$. nervosa, Table 2).

Drought stress resulted in decreased stomatal conductance (gs compared to control conditions for both species, principally at the end of the drought stress period (21/11/ 08; 01/12/08; 03/12/08; Fig. 3). Reductions in gs were more pronounced in $N$. obliqua (approximately $80 \%$ ) than in $N$. nervosa. N. obliqua had a trend to higher values of gs than $N$. nervosa under control conditions, showing significant differences only on one date $(01 / 12 / 08, p=0.0397)$ for midmorning measurements as well for afternoon measurements. Under drought stress conditions both species showed similar stomatal conductance. When analyzing the stomatal behavior of each provenance within each species $(n=5)$, there was no difference between them (data not shown).

Both species had similar, high stomatal sensitivity to VPD under low soil water availability, decreasing from maximum gs values at about $1 \mathrm{kPa}$ to 10 and $20 \%$ of maximum gs at a VPD of about $1.8 \mathrm{kPa}$, in $N$. nervosa and $N$. obliqua, respectively (Fig. 4). Only when relatively high VPD (about $2 \mathrm{kPa}$ or higher) was combined with very low soil water availability, both species closed their stomata almost completely. However, considering dates with low water availability but low VDP (24-11-08 and 26-11-08 in Fig. 3), mean values of gs were 0.036 and $0.044 \mathrm{~mol} \mathrm{H}_{2} \mathrm{O} \mathrm{m}^{-2} \mathrm{~s}^{-1}$ for $N$. nervosa and 0.049 and $0.057 \mathrm{~mol} \mathrm{H}_{2} \mathrm{O} \mathrm{m}^{-2} \mathrm{~s}^{-1}$ for $N$. obliqua in control and stressed conditions, respectively, demonstrating no stomatal closure in plants growing under low soil water conditions. In contrast, on dates with high VDP and low water availability (01-12-08 and 03-12-08), mean values of gs were 0.062 and $0.015 \mathrm{~mol}_{2} \mathrm{O}$ for $N$. nervosa and 0.097 and $0.012 \mathrm{~mol} \mathrm{H}_{2} \mathrm{O}$ for $N$. obliqua in control and stressed conditions, with both species showing a marked decrease in gs (Fig. 3).

In relation to instantaneous water use efficiency (WUE), within each treatment both species had similar WUE values 
(Table 2). Considering treatment effects, $N$. nervosa had similar WUE values regardless of the treatment considered $\left(4.0 \pm 1.1\right.$ and $3.5 \pm 2.4 \mu \mathrm{mol} \mathrm{CO} \mathrm{mmol}^{-1} \mathrm{H}_{2} \mathrm{O}$ for control and stressed plants), while $N$. obliqua reduced its WUE ( $p=0.0311)$ under drought treatment compared to control conditions $(3.9 \pm 1.0$ and $3.1 \pm 1.1 \mu \mathrm{mol}$ $\mathrm{CO}_{2} \mathrm{mmol}^{-1} \mathrm{H}_{2} \mathrm{O}$, respectively). Differences in WUE values were mainly due to reductions in $A_{\text {net }}$ ( $86 \pm 8 \%$ of reduction). Again, no difference was observed between provenances within each species in the WUE patterns (data not shown).

Additional measurements

Results of $P-V$ curves (Table 2) showed that both species had similar $\mathrm{RWC}_{\text {apop }}$ and $\varepsilon_{\max }$ values. In contrast, $N$. nervosa had higher $\Psi_{\pi \mathrm{sat}}$ values $(p=0.0167)$ than N. obliqua (Table 2).

Considering A-Ci curves (Fig. 5), N. obliqua had higher values of $V$ cmax $(46.89 \pm 21.66$ vs. $28.91 \pm 12.57$ $\left.\mu \mathrm{mol} \mathrm{m} \mathrm{s}^{-1}\right), \quad J \quad(80.52 \pm 13.00 \quad$ vs. $\quad 47.88 \pm 9.57$ $\left.\mu \mathrm{mol} \mathrm{m} \mathrm{s}^{-2}\right)$, TPU $(7.20 \pm 1.34$ vs. $3.94 \pm 0.87)$ and $\operatorname{Rd}\left(2.07 \pm 1.42\right.$ vs. $\left.1.80 \pm 1.31 \mu \mathrm{mol} \mathrm{m}^{-2} \mathrm{~s}^{-1}\right)$ than N. nervosa.

There were differences between the species regarding vulnerability to drought-induced xylem cavitation, ( $\left.F_{\text {obs. }}=0.012<F_{\text {crit }}=1.61\right)$. The values for $b$ were higher in Nothofagus nervosa $(-1.13 \mathrm{MPa})$ than in N. obliqua (-1.53 MPa, Table 2). The values for $a$ were similar in both species (Table 2). Maximum hydraulic conductivity values $\left(k_{\max }, \mathrm{ml} \mathrm{cm} \mathrm{H}_{2} \mathrm{O} \mathrm{MPa} \mathrm{s}{ }^{-1}\right.$; Table 2) were higher for $N$. obliqua than for $N$. nervosa (Table 2).

Apex mortality

No mortality was observed in any seedling, regardless of the species, during the experiment in the control treatment (100\% survival). Drought stress had an effect on plant apex survival $(p=0.0055)$, with no significant difference between species $(p>0.05)$. Apex mortality was $23 \%$ for $N$. nervosa and $35 \%$ for $N$. obliqua.

\section{Discussion}

Seasonal water shortage is the main factor constraining survival and growth of woody plants in ecosystems with Mediterranean-type climate (López et al. 2009). Considering the seedling water status (water potential) in our study, we observed that $N$. obliqua reached lower water potential values in most situations (low-high soil water content, pre-dawn or midday) than $N$. nervosa, although statistical differences were only observed at midday when 
Fig. 3 Stomatal conductance ( $g s \mathrm{~mol} \mathrm{H} \mathrm{O}_{2} \mathrm{~m}^{-2} \mathrm{~s}^{-1} \pm \mathrm{SD}$ ) of each species throughout the study period. Different lowercase letters indicate statistical differences in $g s$ between species within treatments. Different capital letters indicate statistical differences in $g s$ between treatments within species. Nn N. nervosa, No N. obliqua, $-C$ control, $-S$ stressed

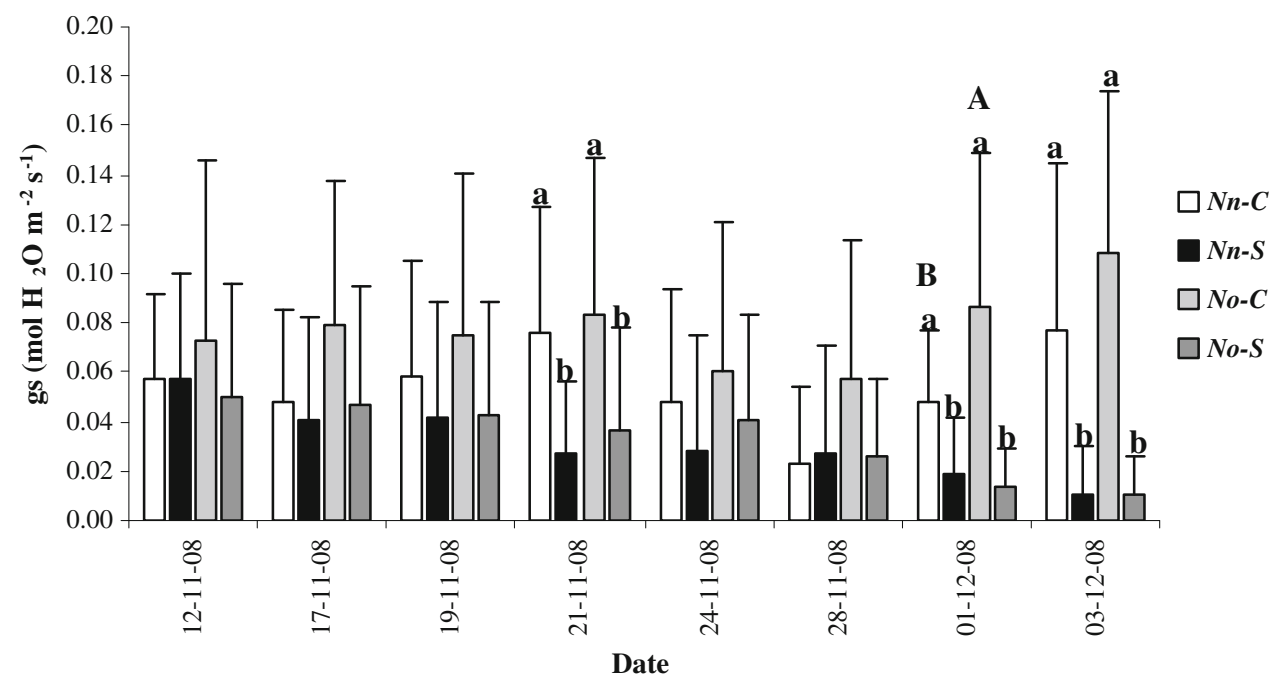

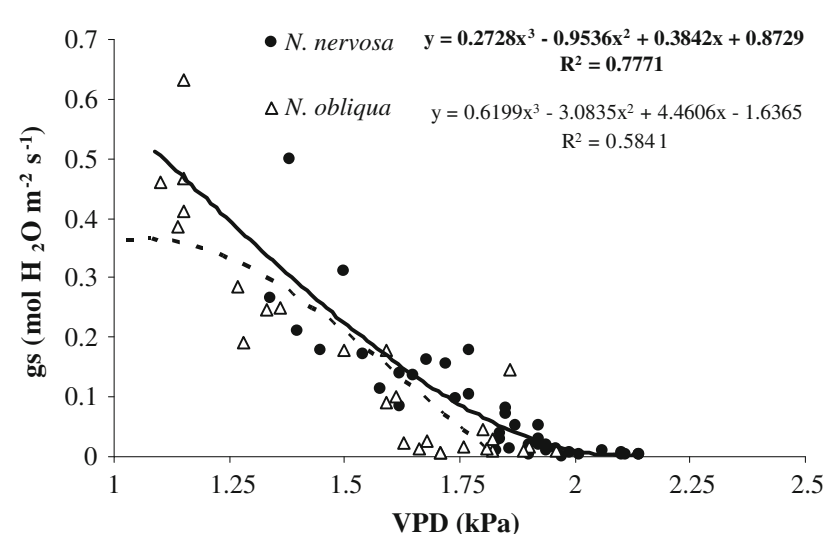

Fig. 4 Relation between stomatal conductance $\left(g s \quad \mathrm{~mol} \mathrm{H}_{2} \mathrm{O}\right.$ $\left.\mathrm{m}^{-2} \mathrm{~s}^{-1}\right)$ and vapor pressure deficit (VPD $\left.\mathrm{kPa}\right)$ in $N$. nervosa and N. obliqua

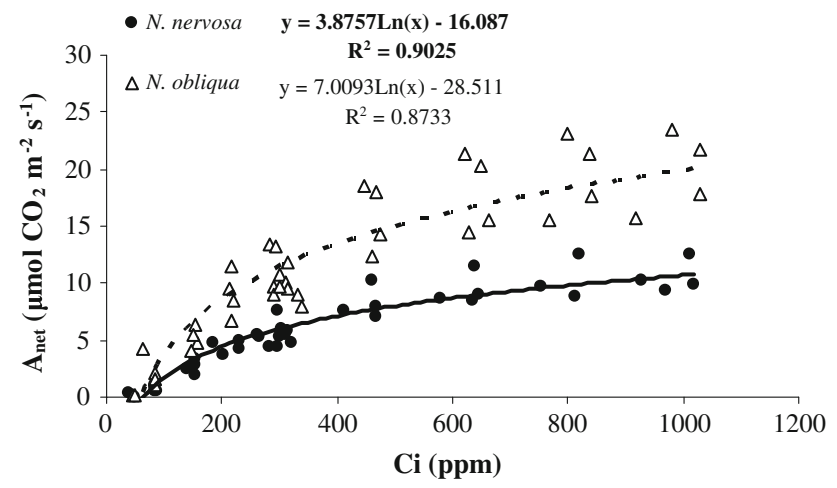

Fig. 5 Net photosynthetic activity $\left(A_{\text {net }} \mu \mathrm{mol} \mathrm{CO} \mathrm{Cm}^{-2} \mathrm{~s}^{-1}\right)$ versus $\mathrm{CO}_{2}$ internal concentration for $N$. nervosa and $N$. obliqua

soil water content was high. These lower values of midday water potential registered for control $N$. obliqua seedlings compared to $N$. nervosa could be related to their lower osmotic potential values at full turgor $\left(\Psi_{\pi \mathrm{sat}}, p=0.0167\right)$, and/or a higher stomatal conductance at that time of the day if soil water content is high. Both facts could imply an advantage for $\mathrm{C}$ fixation under low to moderate stress conditions.

On the other hand, the lower water potential values observed in $N$. obliqua might suggest a greater ability to withstand relatively high xylem tensions, which, if accompanied by a hydraulic conductance higher than or similar to that of $N$. nervosa, could yield a greater capacity for water transport (at least under moderate levels of water stress). In this regard, based on cavitation vulnerability curves and hydraulic conductivity measurements, we can conclude that $N$. obliqua stems have higher specific hydraulic conductivity and somewhat lower vulnerability to cavitation than $N$. nervosa stems, leading it to sustain higher stomatal conductance under non-severe drought conditions. However, midday water potential values recorded for each species suggested that they are probably losing a certain percentage of hydraulic conductivity, suggesting a strategy of maximization of $\mathrm{C}$ fixation even at the expense of substantial losses of hydraulic integrity.

From the vulnerability to drought-induced xylem cavitation measurements, we can see that the values of leaf water potential reached by plants under severe drought conditions and plants under adequate water supply were correlated to approximately $50 \%$ loss of hydraulic conductivity or even higher values (parameter $b$ in Table 2).

Premature leaf abscission has been observed in deciduous Nothofagus species in response to summer drought (Veblen et al. 1996), but was not observed in the present short-term experiment. This leaf abscission could be a good drought avoidance mechanism, preventing xylem dysfunction or alternatively, could occur as a consequence of this dysfunction due to a poor stomatal control of leaf water potential. Our results suggest that the former possibility is more probable if summer drought is characterized not only 
by low rainfall, but also by high VPD. In the case of the species studied, pre-formed leaf senescence would leave aside the neo-formed leaves (leaves developed during the growing season) which may respond differentially to other types of stress or higher intensities of the same stress factor (Guédon et al. 2006; Puntieri et al. 2007). Within the context of tolerance to drought, the recovery rate may be a very important factor for plant adaptation and survival in a particular habitat (Gallé and Feller 2007).

Nothofagus obliqua had higher photosynthetic capacity than $N$. nervosa, due both to characteristics of its hydraulic architecture and to its higher metabolic capacity. In this regard, almost all parameters of the $A-\mathrm{Ci}$ curves were higher in $N$. obliqua than in $N$. nervosa. However, under low water availability conditions, net photosynthetic activity $\left(A_{\text {net }}\right)$ of $N$. obliqua was similar to that of $N$. nervosa, suggesting a higher relative decrease. The average $A_{\text {net }}$ reduction in stressed seedlings was about $80 \%$ compared to the control plants. Similar results were found in other related species and genera (Leuzinger et al. 2005; Gallé and Feller 2007). These reductions may be due in part to a decrease in gs, especially if VPD is high, but an additional effect of some degree of damage of the photosynthetic apparatus must be considered for both species to explain photosynthesis reductions. Considering the results from seedlings under suitable water conditions, both species had mean values of net photosynthetic rate similar to those found in other species of the genus (Read and Hill 1985; Martinez Pastur et al. 2007; Piper et al. 2007; Peri et al. 2009) and related genera (e.g. Leuzinger et al. 2005; Gallé and Feller 2007).

The observed pattern of a reduction in instantaneous WUE of $N$. obliqua under drought conditions is not a common response to water stress, but has been observed in Austrocedrus chilensis (D. Don) Pic. Ser. et Bizarri, another native tree species of Patagonia (Gyenge et al. 2007). Generally, increased WUE is observed with moderate stress, but as stress becomes severe, WUE decreases again (e.g. Eastman and Camm 1995). In this regard, many studies have described the increase in WUE as a common plant response to water shortage (Sultan et al. 1998; Ogaya and Peñuelas 2003; Yin et al. 2005; Piper et al. 2007). In our study, $N$. obliqua WUE decreased in stressed plants compared to controls, suggesting some kind of damage in the photosynthetic apparatus.

When compared to values of other species growing under Mediterranean and temperate climate (Maherali et al. 2004), the observed absolute values of minimum water potential (midday) indicate that both $N$. obliqua and $N$. nervosa should be included within the group of the most susceptible species to air embolisms (cavitation). Nevertheless, the values are consistent with those found for other genera closely related to Nothofagus, such as Quercus and
Fagus (Leuzinger et al. 2005), which survived under moderate water stress conditions. It appears that the very high vulnerability to cavitation of both species studied may only be compatible with survival under conditions of no stress or moderate stress. Interestingly, both species presented a trend consistent with anisohydric control of water potential (Fig. 2c), reaching lower midday water potential values as pre-dawn water potential decreases. The high vulnerability to cavitation in combination with the observed anisohydric-like behavior could imply important losses of hydraulic conductivity under water shortages. In this regard, the anisohydric behavior does not correspond to the typical anisohydric behavior sensu Tardieu and Simoneau (1998). In the species studied, this mechanism may be the result of a lack of stomatal control of transpiration and water potential under soil water shortage, probably linked to the lack of severe water stress they had to withstand within the range of current and past geographical distribution during the growth season. In this regard, both species naturally grow on udic-humidity soils, with no or low water deficits throughout the year (Ferrer et al. 1990).

Although both species showed reductions in gs in response to water stress, the differences in gs between control and stressed plants were significant only on days with high VPD levels, indicating the synergic interaction between low soil water content and high evaporative demand acting as a signal for stomatal closure. Therefore, the anisohydric behavior observed in both species studied would suggest that, rather than being a mechanism of drought resistance, it is a consequence of evolving in environments without severe soil water shortages, resulting in an inability of stomatal regulation when the environmental signal comes from the soil. In addition, when VPD is high (as on the last dates of measurement), no stomatal closure occurs when soil water is also high (control plants), suggesting that this signal alone does not lead to a stomatal response either. In contrast, both species had a high stomatal response to VPD when it was combined with low water availability, indicating that the interaction of factors (high atmospheric demand-low soil water) is the trigger signal of isohydric behavior, mediated by rapid stomatal closure. Similar behavior has been observed in Fagus sylvatica (Lendzion and Leuschner 2008) and in ongoing studies in seedlings of the subtropical species Pinus taeda (Bulfe, per. comm.). The high decrease in gs at VPD values as low as $2 \mathrm{kPa}$, ranging from 0 to $10-20 \%$ of maximum gs depending on soil water availability, is in agreement with the high minimum values of observed leaf water potential, indicating a narrow range of environmental conditions in which these plants can maintain high $\mathrm{C}$ fixation values. Similar behavior has also been observed in adult plants of other Patagonian native woody species (Nothofagus antarctica, Lomatia hirsuta, Schinus patagonicus, Diostea 
juncea and Austrocedrus chilensis), all of which show high minimum water potential values as a consequence of fast stomatal closure (Gyenge et al. 2005, 2008; Fernández et al. 2009). A similar pattern has also been observed in seedlings of other Nothofagus species from New Zealand ( $N$. solandri and $N$. menziesii), both of which are evergreen, and which showed fast stomatal closure in response to dehydrating soil (Sun et al. 1995).

\section{Final conclusions}

As a whole, our results indicate that both species have characteristics of plants susceptible to water stress, showing values of ecophysiological variables similar to species adapted to climates with low to moderate water deficits. Comparing both species, $N$. obliqua had some parameters which conferred an advantage for $\mathrm{C}$ fixation over $N$. nervosa under high soil water availability conditions. We observed lower water potential values in $N$. obliqua suggesting higher stomatal conductance, which are allowed by lower water potential at turgor loss point, higher hydraulic conductivity and lower vulnerability to cavitation than N. nervosa.

Acknowledgments The authors wish to thank Mariana Weigandt and Mariano Beriso for helpful discussions and Fernanda Menni and Cecilia Gittins for their assistance with GLZ models. This study was supported by project PNFOR4232, INTA, Argentina.

\section{References}

Aranda I, Gil L, Pardos JA (2004) Osmotic adjustment in two temperate oak species [Quercus pyrenaica Willd and Quercus petraea (Matt.) Liebl] of the Iberian Peninsula in response to drought. Invest Agrar Sist Recur For 13:339-345

Barbero F (2008) Desarrollo de un Sistema de Información Geográfica (SIG) para determinar áreas potenciales de cultivo de Nothofagus nervosa ("Raulí") y Nothofagus obliqua ("Roble Pellín") en la Provincia de Río Negro a nivel de pre-factibilidad. Informe de Trabajo Final, Facultad de Ciencias Agrarias y Forestales, Universidad Nacional de La Plata, 27

Cochard H, Martin R, Gross P, Boget-Triboulot MB (2000) Temperature effects on hydraulic conductance and water relations of Quercus robur L. J Exp Bot 51:1255-1259

Corcuera L (2003) Respuesta al clima de distintas especies del género Quercus: Estructura y funcionamiento comparado. $\mathrm{PhD}$ Thesis, University of Lérida, Spain

Corcuera L, Camarero JJ, Gil-Pelegrín E (2002) Functional groups in Quercus species derived from the analysis of pressure-volume curves. Trees 16:465-472

Donoso P, Donoso C, Baldini A, Gallo L, Escobar B, Azpilicueta M (2007) Nothofagus obliqua (Mirb.) Oerst. Roble, Pellín, Hualle. In: Donoso Zegers P (ed) Las especies arbóreas de los bosques templados. Autoecología, Chile, pp 471-485

Eastman PA, Camm EL (1995) Regulation of photosynthesis in interior spruce during water stress: changes in gas exchange and chlorophyll fluorescence. Tree Physiol 15:229-235
Ethier GJ, Livingston NJ (2004) On the need to incorporate sensitivity to $\mathrm{CO}_{2}$ transfer conductance into the Farquhar-von CaemmererBerry leaf photosynthesis model. Plant Cell Environ 27:137-153

Ewers BE, Oren R (2000) Analysis of assumptions and errors in the calculation of stomatal conductance from sap flux measurements. Tree Physiol 20:579-589

Fernández ME, Gyenge JE, Schlichter T (2009) Water flux and canopy conductance of natural versus planted forests in Patagonia, South America. Trees 23:415-427

Ferrer J, Irisara J, Mendia J (1990) Estudio Regional de Suelos de la Provincia de Neuquén. CFi. Bs As Vol I, T 2:159, T3:232

Gallé A, Feller U (2007) Changes of photosynthetic traits in beech saplings (Fagus sylvatica) under severe drought stress and during recovery. Physiol Plantarum 131:412-421

Gallo L, Donoso C, Donoso P (2004) Variación en Nothofagus nervosa (Phil.) Dim. et Mil. (N. alpina, N. procera). In: Donoso C, Premoli A, Gallo L, Ipinza R (eds), Variación intraespecifica en las especies arbóreas de los bosques templados de Chile y Argentina. Editorial Universitaria 420

Gallo L, Marchelli P, Chauchard L, Gonzales Peñalba M (2009) Knowing and doing: research leading to action in the conservation of forest genetic diversity of Patagonian temperate forests. Conserv Biol 23:895-898

Guédon Y, Puntieri JG, Sabatier S, Barthélémy D (2006) Relative extents of preformation and neoformation in tree shoots: analysis by a deconvolution method. Ann Bot 98:835-844

Gyenge JE, Fernández ME, Dalla Salda G, Schlichter T (2005) Leaf and whole-plant water relations of the Patagonian conifer Austrocedrus chilensis (D. Don) Pic. Ser. et Bizzarri: implications on its drought resistance capacity. Ann For Sci 62:297-302

Gyenge JE, Fernández ME, Schlichter T (2007) Influence of radiation and drought on gas exchange of Austrocedrus chilensis seedlings. Bosque 28:220-225

Gyenge JE, Fernández ME, Schlichter T (2008) Are differences in productivity between native and exotic trees in N.W. Patagonia related to differences in hydraulic conductance? Trees 22: $483-490$

IPCC (Intergovernmental Panel on Climate Change) (2008) Climatic change and water. Intergovernmental Panel on Climate Change. In: Bates B, Kundzewicz Z, Wu S, Palutikof J (eds) IPCC Technical Paper VI. WMO y UNEP

Jobbágy EG, Sala OE, Paruelo JM (1995) Patterns and controls of primary production in the Patagonian steppe: a remote sensing approach. Ecology 83:307-319

Kozlowski TT, Pallardy SG (2002) Acclimation and adaptive responses of woody plants to environmental stresses. Bot Rev 68:270-334

Lemoine D, Cochard H, Granier A (2002) Within crown variation in hydraulic architecture in beech (Fagus sylvatica L.): evidence for a stomatal control of xylem embolism. Ann For Sci 59:19-27

Lendzion J, Leuschner C (2008) Growth of European beech (Fagus sylvatica L.) saplings is limited by elevated atmospheric vapor deficits. For Ecol Manag 256:648-655

Leuzinger S, Zotz G, Asshoff R, Körner C (2005) Responses of deciduous forest trees to sever drought in Central Europe. Tree Physiol 25:641-650

López R, Rodriguez-Calcerrada J, Gil E (2009) Physiological and morphological response to water deficit in seedlings of five provenances of Pinus canariensis: potential to detect variation in drought tolerance. Trees 23:509-519

Maherali H, DeLucia EH (2000) Interactive effects of elevated $\mathrm{CO}_{2}$ and temperature on the water transport of ponderosa pine. Am J Bot 87:243-249

Maherali H, Pockman W, Jackson R (2004) Adaptative variation in the vulnerability of woody plants to xylem cavitation. Ecology 85:2184-2199 
Marchelli P (2001) Variabilidad genética en Raulí (Nothofagus nervosa (Phil.) Dim. Et Mil., su relación con procesos evolutivos y la importancia en la conservación y utilización de sus recursos genéticos. Tesis Universidad Nacional del Comahue, Bariloche, 222

Martinez Pastur G, Lencinas MV, Peri P, Arena M (2007) Photosynthetic plasticity of Nothofagus pumilio seedlings to light intensity and soil moisture. For Ecol Manag 243:274-282

Martinez-Ferri E, Balaguer L, Valladares F, Chico JM, Manrique E (2000) Energy dissipation in drought-avoiding and drought tolerant tree species at midday during Mediterranean summer. Tree Physiol 20:131-138

McDowell N, Pockman W, Allen CD, Breshears DD, Cobb N, Kolb T, Plaut J, Sperry J, West A, Williams DG, Yepez EA (2008) Mechanisms of plant survival and mortality during drought: why do some plants survive while others succumb to drought? New Phytol 178:719-739

Ogaya R, Peñuelas J (2003) Comparative field study of Quercus ilex and Phillyrea latifolia: photosynthetic response to experimental drought conditions. Environ Exp Bot 50:137-148

Oren R, Sperry JS, Katul GG, Pataki DE, Ewers BE, Phillips N, Shäfer KVR (1999) Survey and synthesis of intra-and interspecific variation in stomatal sensitivity to vapor pressure deficit. Plant Cell Environ 22:1515-1526

Pammenter NW, Vander Willigen C (1998) A mathematical and statistical analysis of the curves illustrating vulnerability of xylem to cavitation. Tree Physiol 18:589-593

Peri P, Martinez Pastur G, Lencinas MV (2009) Photosynthetic response to different light intensities and water status of two main Nothofagus species of southern Patagonian forest, Argentina. J For Sci 55:101-111

Piper F, Corcuera LJ, Lusk C (2007) Differential photosynthetic and survival responses to soil drought in two evergreen Nothofagus species. Ann For Sci 64:447-452

Pratolongo P, Quintana R, Malvarez I, Cagnoni M (2003) Comparative analysis of variables associated with germination and seedling establishment for Prosopis nigra (Griseb.) Hieron and Acacia caven (Mol.) Mol. For Ecol Manag 179:15-25

Premoli A (2004) Variación en Nothofagus pumilio (Poepp. et Endl.) Krasser. In: Donoso C, Premoli A, Gallo L, Ipinza R (eds)
Variación intraespecifica en las especies arbóreas de los bosques templado de Chile y Argentina. Editorial Universitaria, pp 420

Puntieri J, Grosfel J, Stecconi M, Brion C, Azpilicueta MM, Gallo L, Barthélémy D (2007) Shoot development and dieback in progenies of Nothofagus obliqua. Ann For Sci 64:839-844

Read J, Hill RS (1985) Photosynthetic responses to light of Australian and Chilean species of Nothofagus and their relevance to the rainforest dynamics. New Phytol 101:731-742

Sharkey TD, Bernacchi CJ, Farquhar GO, Singaas EL (2007) Fitting photosynthetic carbon dioxide response curves for $\mathrm{C} 3$ leaves. Plant Cell Environ 30:1035-1040

Suarez ML, Germandi L, Kitzberger T (2004) Factors predisposing episodic drought-induced tree mortality in Nothofagus-site, climatic sensitivity and growth trends. J Ecol 92:954-966

Sultan SE, Wilczek AM, Bell DL, Hand G (1998) Physiological response to complex environments in annual Polygonum species of contrasting ecological breadth. Oecologia 115:564-578

Sun OJ, Sweet GB, Whitehead D (1995) Physiological responses to water stress and waterlogging in Nothofagus species. Tree Physiol 15:629-638

Tardieu F, Simoneau T (1998) Variability among species of stomatal control under fluctuating soil water status and evaporative demand: modeling isohydric and anisohydric behaviours. J Exp Bot 49:419-432

Tyree M, Sperry J (1988) Do woody plants operate near the point of catastrophic xylem dysfunction caused by dynamic water stress? Answers from a model. Plant Physiol 88:574-580

Valladares F (2004) Global change and radiation in Mediterranean forest ecosystems: a meeting point for ecology and management. In: Arianoutsou, Papanatasis (eds) Proceedings 10th Medecos conference, 25 April-1 May, Rhodes, Greece. ISBN:90 5966 0161

Veblen TT, Donoso C, Kitzberger T, Rebertus AJ (1996) Ecology of southern Chilean and Argentinean Nothofagus forests. In: Veblen TT, Hill RS, Read J (eds) The ecology and biogeography of Nothofagus forests. Yale University Press, New Haven, CT, pp 293-353

Yin C, Peng Y, Zang R, Zhu Y, Li C (2005) Adaptative responses of Populus kangdingensis to drought stress. Physiol Plantarum 123:445-451 